\title{
COMPARATIVE STUDY OF DIFFERENTIAL LEUCOCYTE COUNT BY MANUAL AND AUTOMATED METHOD
}

\author{
Vipina $K^{1}$, Ambika $V^{2}$
}

1 Postgraduate Student, Department of Pathology, Government Medical College, Trivandrum.

${ }^{2}$ Assistant Professor, Department of Pathology, Government Medical College, Manjeri, Kerala.

\section{BACKGROUND}

\section{ABSTRACT}

Today, the white blood cell differential remains one of the most frequently performed tests in laboratory. In a developing country like India, automated machines are not available in many laboratories and they resort to manual DLC. This study is an attempt to check the accuracy of manual DLC.

\section{MATERIALS AND METHODS}

Study was carried out in Government Medical College, Kozhikode. A total of 30 cases were taken over a period of 28 days (from $1 / 4 / 2015-28 / 4 / 2015)$.

\section{RESULTS}

In each sample, DLC was done manually and in automated machine. Values were statistically analysed.

\section{CONCLUSION}

Manual DLC is fairly accurate but of poor precision, whereas automated is precise.

\section{KEYWORDS}

CBC- Complete Blood Count, DLC- Differential Leucocyte Count, EDTA- Ethylenediaminetetraacetic Acid.

HOW TO CITE THIS ARTICLE: Vipina K, Ambika V. Comparative study of differential leucocyte count by manual and automated method. J. Evolution Med. Dent. Sci. 2018;7(03):328-331, DOI: 10.14260/jemds/2018/73

\section{BACKGROUND}

Today, the white blood cell differential remains one of the most frequently performed tests in laboratory. Until 1970s, only method generally accepted to perform DLC was microscopic examination of Romanowsky stained blood smear by laboratory technicians.(1)

The white cell differential part of the DLC has traditionally included the counting and categorisation of 100 cells based on pre-established morphological criteria with the result expressed as percentage of cell type identified.(2)

Traditionally performed manual DLC has limitations including poor sensitivity, specificity and predictive value, also being imprecise due to sampling error, statistical probability and performer's judgemental errors. This has provided a sound basis for the need to automate the DLC. In recent years, there was rapid progress in automated machines in laboratories. But the resources are inadequate in many specialised centres in India, hence they resort to manual differential white cell count which are subjected to both inaccuracy and imprecision. Automated counts are generally fairly precise, but are sometimes inaccurate.(3)

This study is an attempt to check the accuracy of manual with respect to automated differential counts.

'Financial or Other Competing Interest': None.

Submission 03-11-2017, Peer Review 27-12-2017,

Acceptance 04-01-2018, Published 13-01-2018.

Corresponding Author:

Dr. Ambika V,

Kadaksham,

Eranhipalam,

Kozhikode.

E-mail: drambikav@gmail.com

DOI: $10.14260 /$ jemds $/ 2018 / 73$

\section{Aims and Objectives}

- To compare the white cell differential count from Leishman-stained peripheral smear and automated cell count.

- To check the accuracy of white cell differential from peripheral smear.

\section{MATERIALS AND METHODS}

This study which is a descriptive study was carried out in Pathology Department at Govt. Medical College, Calicut, from $1 / 4 / 2015$ to $28 / 4 / 2015.30$ Random blood samples collected from the patients by venepuncture and taken in an EDTA bottle were used for the study.

\section{Inclusion Criteria}

Samples of patients without haematological abnormality was taken.

\section{Exclusion Criteria}

Clotted samples and samples without proper label were excluded.

\section{Methods}

The white cell differential count of each sample is estimated by both manual and automated methods.

\section{Manual Method}

Number of different types of blood cells out of 100 cells present in the blood were counted by examining a Leishmanstained peripheral smear under oil immersion objective. The area where the RBCs just touches each other was selected for counting.(4) 


\section{Preparation of Peripheral Smear}

Clean slides were taken, small pipette were used to get blood drop of adequate size, that is $2 \mathrm{~mm}$ in diameter. Smears were prepared as per the two slide method/ wedge method. Slides labelled with number of the patient and date of preparation using a pencil near the head of the smear.(5)

\section{Staining of Blood Smear}

After preparation the blood smears were stained as soon as possible, if there was delay smears fixed by dipping in methanol for 1 - 2 seconds, air dried and stored until ready to be stained. Romanowsky stains were used which contain methylene blue (a basic dye), eosin (an acidic dye) and polychrome methylene blue or methylene azure. In this study, we used Leishman-stains, which was prepared using solution 1 and solution 2 .

\section{Solution 1}

Contains methylene blue $1 \mathrm{~g}$, sodium carbonate $100 \mathrm{~mL}$, eosin ( $0.1 \%$ aqueous solution) $100 \mathrm{~mL}$.

\section{Solution 2}

Buffer solution (pH 6.8) contains Disodium hydrogen phosphate $\mathrm{m} / 15$ solution, Potassium dihydrogen phosphate $\mathrm{m} / 15$ solution. After staining slides were washed with buffer solution, drained and dried in air.

The differential WBC count is best done in the area of the smear, where RBCs are separated and not overlapping. The differential count on a regular blood smear may vary somewhat depending upon the area of slide used for counting.

The length-wise strip method has a slightly better distribution than the sidewise strips. The five types of white blood seen in blood are neutrophils, eosinophils, basophils, monocyte and lymphocyte.

Neutrophils- cells with acidophilic cytoplasm and fine pinkish red granules. The nucleus is the lobulated (3 - 5) lobes connected by thin chromatin filament.

Eosinophils are acidophilic cells larger than neutrophils. Cytoplasm contain bright red orange granules and nucleus bilobed.

Basophils are slightly smaller than neutrophils, average diameter being 10 microns, nucleus may have two or more lobes. Cytoplasm contain large granules, which stain purple or black nucleus obscured by the granules.

Monocytes are the largest measuring 16 - 20 microns in diameter, nucleus large, oval/ lobular/ kidney shaped, cytoplasm abundant and stains greyish-blue, few extremely fine azurophilic granules called azure dust may be seen in cytoplasm.

Lymphocytes in the peripheral smear appear in two forms, small lymphocytes and large lymphocytes.

The small lymphocyte is more frequently seen in adult blood. The nucleus is round and stains deep purple. Cytoplasm appears as dark blue band around the nucleus.

The large lymphocyte has a slightly large nucleus and abundant cytoplasm. The nucleus stains lightly as compared to that of the small lymphocyte. The cytoplasm is pale blue in colour. The differential WBC count should be done under oil immersion after first scanning the smear under low power.

Usually 100 cells are counted, though a count of 200 cells would increase the accuracy and the number of each cell type counted expressed in percentage. The error of the count will be of the order of $+/-10 \%$ if we count 100 cells or of $+/-7 \%$ if we count 200 cells.(6)

\section{Automated Method}

The cell counter Sysmex KX-21 was used for doing the white cell differential automatically. This offers fully automatic sample aspiration and dilution and can provide 18 parameter test results. The KX-21 analyser with a throughput capacity of 60 samples per hour can run the sample in whole blood mode and pre-dilute mode. In pre-diluted mode, samples are diluted in a ratio of 1: 26 with Cell Pack.(7)

With this device factors such as WBC, RBC, HGB, HCT, MCV, MCH, MCHC, PLT, NEUT\%, LYMPH\%, MXD\%, NEUT\#, LYMPH\#, MXD\#, RDW-SD or RDW-CV, PDW*, MPV and P$\mathrm{LCR}^{*}$ can be analysed in whole blood mode operation. Predilute mode can analyse parameters such as WBC, RBC, HGB, HCT, MCV, MCH, MCHC and PLT. Among the features of this instrument were automatic self-testing start-up, on board storage for 240 test results and single start button operation.

The KX use three detectors block and two kinds of reagents for blood analysis. The WBC count measured by the WBC detector block using the DC detection count and platelets are taken by the RBC detection block, also using the DC detection methods, the HGB detectors block measure the concentration of haemoglobin using non-cyanide haemoglobin method.(8)

\section{Technique}

- Mix the EDTA sample by inverting the tube.

- $\quad$ Remove the plug while taking care not to allow blood scatter.

- $\quad$ Set the tube to sample probe. Press the start button. The volume of sample aspirated is $\mathbf{5 0}$ microlitre.

- The buzzer sounds two times- "beep, beep"- and the LCD screen display 'analysing.' After unit execute automatic analysis and display the result on LCD screen remove the tube.

- Analysis result printed out on built-in printer.

- The unit automatically turns to ready status, becoming ready for analysis of next sample.

Normal value in an adult are neutrophil: 40\%-75\%, eosinophils: $1 \%-4 \%$, Basophils: $0 \%-1 \%$, Lymphocyte: $20 \%$ 45\%, Monocytes: $2 \%-8 \%$.

\section{Statistical Analysis}

Cohen's Kappa using SPSS version 23.0 Statistics.

\section{RESULTS}

In this descriptive study, 30 blood samples from patients coming to OP department was collected. Differential counts were taken manually on Leishman-stained peripheral smears and in automated machines. Automated machine was 3 part, hence in manual counting in DC only neutrophils, lymphocytes and mixed population was taken. In manual DLC on an average, neutrophils showed a minimum value of 38 and maximum of 89. Lymphocyte had a minimum of 4 and maximum of 50, while mixed cells had 8 and 16 respectively.

Neutrophils in manual count showed a mean difference of 68.9, while in automated it was 61.17 (Table 1). Lymphocytes and mixed cells showed mean difference of 28.70 and 2.60 
respectively in manual method, while automated method showed 30.60 and 11.25 (Table 3). On comparison of the performance by descriptive statistics of 3-part leukocyte difference in Sysmex KX-21 with manual method of $90 \%$ correlation was obtained in this study.

In statistical analysis, Cohen's Kappa using SPSS was used to assess external validity and rater reliability. Comparative analysis showed that lymphocyte values correlated well with the result obtained from the analyser differential using the Sysmex KX-21 with a Kappa $=.689(\mathrm{p}=.000)$; however, neutrophil count correlated less, Kappa $=.512(\mathrm{p}=.002)$ (Table 2 and 3 ).

On descriptive statistical analysis of neutrophil count between two methods showed a mean difference of 7.73 and standard deviation of 6.8. This showed a less correlation. Lymphocyte and monocyte showed a minimal difference $(<1)$ and the correlation was good.

\begin{tabular}{|c|c|c|c|c|c|}
\hline & No. & $\begin{array}{c}\text { Mini- } \\
\text { mum }\end{array}$ & $\begin{array}{c}\text { Maxi- } \\
\text { mum }\end{array}$ & Mean & $\begin{array}{c}\text { Std. } \\
\text { Deviation }\end{array}$ \\
\hline $\begin{array}{c}\text { Neutrophil } \\
\text { Manual }\end{array}$ & 30 & 44 & 95 & 68.90 & 13.817 \\
\hline $\begin{array}{c}\text { Neutrophil } \\
\text { Automated }\end{array}$ & 30 & 32 & 89 & 61.17 & 15,991 \\
\hline $\begin{array}{c}\text { Lymphocyte } \\
\text { Manual }\end{array}$ & 30 & 4 & 54 & 28.57 & 13.635 \\
\hline $\begin{array}{c}\text { Lymphocyte } \\
\text { Automated }\end{array}$ & 30 & 7 & 96 & 30.70 & 21.224 \\
\hline $\begin{array}{c}\text { Mixed } \\
\text { Manual }\end{array}$ & 30 & 0 & 9 & 2.60 & 2.127 \\
\hline $\begin{array}{c}\text { Mixed } \\
\text { Automated }\end{array}$ & 30 & 2 & 28 & 11.25 & 5.875 \\
\hline \multicolumn{7}{|c|}{ Table 1. Comparison of the Performance } \\
by Descriptive Statistics
\end{tabular}

\begin{tabular}{|c|c|c|c|c|c|c|c|c|}
\hline \multirow{3}{*}{$\begin{array}{c}\text { Neutrophil } \\
\text { Manual }\end{array}$} & \multicolumn{6}{|c|}{ Neutrophil Automated } & \multirow{2}{*}{\multicolumn{2}{|c|}{ Total }} \\
\hline & \multicolumn{2}{|c|}{ Low } & \multicolumn{2}{|c|}{ Normal } & \multicolumn{2}{|c|}{ High } & & \\
\hline & $\ddot{\Xi}$ & de & $\ddot{\Xi}$ & a & $\vec{\Xi}$ & ¿ & $\ddot{\Xi}$ & de \\
\hline Normal & 2 & 6.7 & 16 & \begin{tabular}{|l|}
53.3 \\
\end{tabular} & 2 & 6.7 & 20 & 66.7 \\
\hline High & 0 & 0.0 & 3 & \begin{tabular}{|l|}
10.0 \\
\end{tabular} & 7 & 23.3 & 10 & 33.3 \\
\hline Total & 2 & 6.7 & 19 & 63.3 & 9 & 30.0 & 30 & 100.0 \\
\hline \multicolumn{9}{|c|}{ Kappa $=.512(\mathrm{p}=.002)-$ Moderate Agreement } \\
\hline \multicolumn{9}{|c|}{$\begin{array}{c}\text { Table 2. Cohen's Kappa Method to assess External Validity } \\
\text { and Rater Reliability of Neutrophil Count in Manual and } \\
\text { Automated Method }\end{array}$} \\
\hline
\end{tabular}

Kappa $=.689(\mathrm{p}=.000)-$ Substantial Agreement

\begin{tabular}{|c|c|c|c|c|c|c|c|c|}
\hline \multirow{3}{*}{$\begin{array}{l}\text { Lymphocyte } \\
\text { Manual }\end{array}$} & \multicolumn{6}{|c|}{ Lymphocyte Automated } & \multirow{2}{*}{\multicolumn{2}{|c|}{ Total }} \\
\hline & \multicolumn{2}{|c|}{ Low } & \multicolumn{2}{|c|}{ Normal } & \multicolumn{2}{|c|}{ High } & & \\
\hline & $\vec{\Xi}$ & 8 & 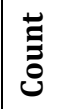 & 8 & $\stackrel{\Xi}{\Xi}$ & 8 & $\ddot{\Xi}$ & $\delta^{\circ}$ \\
\hline Low & 9 & 30.0 & 1 & 3.3 & 0 & 0.0 & 10 & 33.3 \\
\hline Normal & 2 & 6.7 & 15 & 50.0 & 2 & 6.7 & 19 & 63.3 \\
\hline High & 0 & 0.0 & 0 & 0.0 & 1 & 3.3 & 1 & 3.3 \\
\hline Total & 11 & 36.7 & 16 & 53.3 & 3 & 10.0 & 30 & 100.0 \\
\hline Table 3 & & Kapp & $\bar{A}$ & alys & & $m$ & & \\
\hline
\end{tabular}

\section{DISCUSSION}

This study was conducted to check the accuracy of manual white cell differential count with respect to automated method.
Statistical analysis showed manual differential counts were generally fairly accurate, but precision was poor, whereas automated count were precise but sometimes inaccurate. In manual leukocyte counts, 3 main sources of errors encountered were slide-distribution errors, cell recognition errors and statistical sampling errors.

A reference leukocyte differential counting was proposed by the National Committee for Clinical Laboratory Standards.(9) This proposed reference method deals with all the recognised problems that contribute to the imprecision and inaccuracy of the eye-count differential and this was used here.

The slide distribution errors were minimised by selecting proper method for peripheral smear preparation and cell counting. The maldistribution of cells will be aggravated if the film is too thin or a spreader with rough edges were used.(10)

\section{This was avoided using smears of very good quality}

Proper selection of blood film preparation methodologies, which included the following: Wedge method is the commonly used one. The part of the smear away from the start will be too thin, whereas the part near to the start will be too thick for microscopy. The main problem associated with this method was the uneven distribution of the cells. This can be avoided by using spin/ coverslip method. Morphology of all cells are excellent in spin method.(11)

No system of counting will compensate for the gross irregularities in cell distribution, which occur in badly made films. Although, the length-wise strip method gave a slightly better distribution than side-wise strip, the length-wise strips also showed more cells in the thicker central part of the smear.

If Rouleaux is increased on the slide, the cells in the thick part of the cell may not be flattened at all and it may be difficult to differentiate a monocyte from a large lymphocyte. The side-wise strip method assures better morphology of the cells counted, though the distribution is slightly less accurate. So it was found that modified battlement track is a compromise between the two methods.

The error of the count is of the order of $+/-10 \%$ if we count 100 cells or of the order of $+/-7 \%$ if we count 200 cells. Cell recognition errors were related to the observer's level of training, experience, attitude and concentration.

Inadequately prepared films and poor staining also may contribute to this source of error. Marked storage artifact renders a differential count very inaccurate, hence it is best to stain immediately.

Recognition errors also occur in automated leukocyte differential instruments for similar reasons: The recognition system may be unable to distinguish among cell types, because of poor preparations or poor staining or because of inadequate capabilities of the instrument to recognise particular cell types.

Cell recognition errors was detected by two types of methods, cell-by-cell comparison with a human observer or group of human observers and comparison of results with the eye-count differential on the same sample. Both types of comparisons can be made with image processing instruments, but only comparison of cell classification can be done with flow-through cytochemical instruments or the screening differential instruments. 


\section{Statistical Sampling Errors}

This was the largest source of error in the eye-count differential leukocyte count in our study. The small sample size $100 / 200$ cells counted provide only a coarse estimate of the frequencies of occurrence of cell types, especially for the type normally present in low levels such as eosinophils, monocytes and basophils. This statistical sampling problem and the uncertainties are well described by Rumke in his study. But automated instruments that based their differential on 100 or 200 cells also suffered from the same uncertainties.

The flow cytochemical instruments, which count much larger number of cells have much greater precision or reproducibility, because the sampling error is much smaller, but they are very costly and not affordable for many laboratories.

\section{CONCLUSION}

1. DLC has limitations including poor sensitivity, specificity and predictive value besides being imprecise due to sampling error, statistical probability and performer's judgmental errors.

2. Even the most sophisticated cell counting instruments of today still rely upon carefully standardised manual method for primary calibration of their measurements.

3. Manual differential counts are generally fairly accurate, but their precision is poor, whereas automated counts are generally fairly precise.

\section{REFERENCES}

[1] Bain BJ. Morphology of blood cells. In: Blood cells: a practical guide. Philadelphia: JB Lippincott, Company, 1989:55.
[2] Pierre RV. The routine differential leukocyte count vs automated differential counts. Blood Cells 1985;11(1):11-23.

[3] Bull BS, Korpman RA. The logistics of the leukocyte differential count (implications for automation). In: Koepke JA. (eds). Differential leukocyte counting. CAP Conference/Aspen 1977. College of American Pathologists, Skokie, IL; 1978:217-24.

[4] Lewis M. Reference ranges and normal values. In: Lewis SM, Bain BJ, Bates I. (eds). Dacie and Lewis practical haematology. 10. Churchill Livingstone; 2006:11-24.

[5] Whitlock JA, Gaynon PS. Acute lymphoblastic leukemia. In: Lee GR, Forester J, Lukens J, et al. (eds). Wintrobe's clinical hematology. 10 th edn. Baltimore USA. William and Willkins, 1999:2241-71.

[6] Bentley SA, Johnson A, Bishop CA. A parallel evaluation of four automated haematology analyzers. Am J Clin Pathol 1993;100(6):626-32.

[7] Rosvall RV, Mengason AP, Smith L, et al. Visual and automated differential leukocyte count. A comparison study of three instruments. Am J Clin Pathol 1979;71(6):695-703.

[8] Ochei J, Kolhatkar A. Medical laboratory science: theory and practical. Publisher TMGH 2009.

[9] Bull B, Korpman RA. Characterization of the WBC differential count. Blood Cells 1980;6(3):411-9.

[10] Kingsley TC. The automated differential: pattern recognition systems, precision and the spun smear. Blood Cells 1980;6(3):483-7.

[11] Bacus JW. Erythrocyte morphology and centrifugal "spinner" blood film preparations. J Histohem Cytochem 1974;22(7):506-16. 